\title{
POTENSI SITOTOKSIK KOMBINASI EKSTRAK DAUN CAPO DAN DAUN SEMBUNG RAMBAT
}

\author{
Lili Andriani ${ }^{1)}$, Santi Perawati ${ }^{1)}$, Dila Wati ${ }^{1)}$ \\ ${ }^{1}$ Program Studi Farmasi, Sekolah Tinggi Ilmu Kesehatan Harapan Ibu Jambi \\ email: santiperawati@gmail.com
}

\begin{abstract}
Abstrak
Penggunaan obat-obat tradisional masih sangat diyakini oleh masyarakat SAD. Daun capo (Blumea balsamifera (L.) DC.) dan daun sembung rambat (Mikania micrantha Kunth) merupakan tumbuhan yang dimanfaatkan sebagai pengobatan, mengandung berbagai metabolit sekunder dan berpotensi sebagai sitotoksik. Tujuan penelitian ini adalah untuk mengetahui aktivitas sitotoksik dari ekstrak daun capo, ekstrak sembung rambat, serta kombinasi ekstrak capo dan sembung rambat Penelitian ini dilakukan dengan menggunakan metode ekstraksi daun capo dan daun sembung rambat dengan pelarut etanol 70\%. Lalu ekstrak diuji potensi sitotoksiknya menggunakan larva Artemia salina Leach dengan metode BSLT. Hasil penelitian memperlihatkan bahwa nilai LC $_{50}$ pada ekstrak sembung rambat sebesar 28,18 ppm dengan kategori sangat toksik, dan untuk capo sebesar 41,68 ppm dengan kategori kuat. Sedangkan ekstrak kombinasi capo dan sembung rambat didapatkan nilai $\mathrm{LC}_{50}$ sebesar 14,79 ppm dengan kategori sangat toksik. Jadi ekstrak daun sembung rambat dan kombinasi ekstrak memiliki nilai sitotoksik yang lebih tinggi.
\end{abstract}

\section{Kata kunci: Artemia salina Leach; Blumea balsamifera; Ekstrak; Mikania micranta; Sitotoksik}

\begin{abstract}
The use of traditional medicines is still highly believed by the SAD community. Capo leaf (Blumea balsamifera (L.) DC.) and sembung rambat leaf (Mikania micrantha Kunth) are medicinal plants that contain various secondary metabolites and have potential as cytotoxic. The purpose of this study was to determine the cytotoxic activity of capo leaf extract, sembung rambat extract, and the combination of capo and sembung rambat extract. Then the extract was tested for its cytotoxic potential using Artemia salina Leach larvae using the $B S L T$ method. The results showed that the LC50 value for the sembung rambat extract was $28.18 \mathrm{ppm}$ in the very toxic category, and $41.68 \mathrm{ppm}$ for capo in the strong category. While the combined extract of capo and sembung rambat obtained an LC50 value of $14.79 \mathrm{ppm}$ with a very toxic category. So the sembung rambat leaf extract and the combination of extracts had a higher cytotoxic value.
\end{abstract}

Keywords: Artemia salina Leach;Blumea balsamifera; Cytotoxic; Extract; Mikania micrantha. 


\section{PENDAHULUAN}

Penggunaan obat-obat tradisional masih sangat diyakini oleh beberapa masyarakat yang ada di Indonesia termasuk SAD. Pengobatan tradisional untuk menyembuhkan berbagai macam penyakit baik dari kategori penyakit ringan, sedang, sampai dengan berat. Kearifan lokal masyarakat dalam menggunakan pengobatan tradisional melalui berbagai macam jenis tumbuh-tumbuhan dan rempah yang merupakan resep turun-temurun dari leluhur yang tetap dilestarikan (Lesmana et al., 2018). Tumbuhan yang dapat dimanfaatkan sebagai pengobatan capo dan sembung rambat.

Terkait tumbuhan capo yang sudah banyak diteliti meliputi efek antioksidan, antibakteri (Iga, dkk., 2016), antihipertensi (A.bambang.S dkk, 2019), antiinflamasi (F. semiawan, dkk 2015), antiasma (Damayanti, dkk, 2019), dan toksisitas (Aried, dkk 2019). Sembung rambat meliputi efek antibakteri (Mayang Tari, Lidia, 2016), antijamur (Alfiah, dkk, 2015), antikoagulan (Perawati et al., 2019), antioksidan (Apriandi, dkk, 2016), antitumor (Dou et al., 2014), sitotoksik, fitokimia, anthelmitik, trombolitik (Raka et al., 2019).

Pengobatan penyakit tumor sudah banyak dilakukan dalam beberapa tahun terakhir tetapi masih terjadi peningkatan angka kejadian penyakit kanker/tumor di Indonesia (136.2/100.000 penduduk). (Kemenkes RI, 2019). Penggunaan obat herbal dalam pengobatan antitumor telah banyak dilakukan. Obat herbal memiliki efek samping yang lebih rendah dibandingkan dengan penggunaan obat kimia. Penggunaan kombinasi tanaman obat dalam mengobati suatu penyakit sudah banyak dilakukan. Menurut penelitian sebelumnya terkait aktivitas kombinasi ekstrak tanaman sudah banyak dilaporkan diantaranya efek sitotoksik daun petai cina dan kulit jengkol dengan metode BSLT (Noviardi et al., 2019). Kombinasi ekstrak benalu belimbing dan bawang sabrang memiliki aktivitas antikanker dengan metode MTT assay (Mutiah et al., 2017). Penilaian aktivitas sitotoksik daun Mikana micrantha sudah memiliki aktivitas sebagai sitotoksik (Raka et al., 2019). Belum adanya laporan 
pemanfaatan capo dan sembung rambat serta kombinasi capo dan sembung rambat menjadi landasan utama awal pemilihan penelitian ini menggunakan metode BSLT untuk mengetahui efek sitotoksik yang dihasilkan.

\section{METODE PENELITIAN}

\subsection{Alat dan bahan penelitian}

Alat yang akan digunakan pada penelitian ini yaitu, seperangkat rotary evaporator buchi : R-100, timbangan analitik, botol kaca gelap, Erlenmeyer, gelas ukur, batang pengaduk, pemanas, soliter/wadah pembiakan larva, labu ukur, cawan penguap, tabung reaksi, kertas saring, pipet tetes, vial, lampu, Aerator. Bahan yang akan digunakan yaitu simplisia capo, ekstrak sembung rambat, etanol 70\%, aquadest, $\mathrm{HCl} 1 \mathrm{~N}, \mathrm{H}_{2} \mathrm{SO}_{4}$, reagen Mayer, reagen Dragendorf, reagen Wagner, kloroform, air laut, larva udang (Artemia salina Leach).

\subsection{Prosedur Penelitian}

\subsubsection{Determinasi Tumbuhan}

Determinasi tumbuhan dilakukan untuk menghindari kesalahan dalam pengambilan tumbuhan. Determinasi tumbuhan capo dan tumbuhan sembung rambat di Laboratorium Taksonomi Tumbuhan Jurusan Biologi FMIPA UNPAD.

\subsubsection{Pengambilan dan Pengolahan bahan}

Sampel daun capo yang digunakan berasal dari daerah Provinsi Jambi khususnya di Desa Pulau Aro kecamatan Tabir Ulu, Kabupaten Merangin. Daun sembung rambat berasal dari daerah Pulau Tengah, Kabupaten Kerinci, Provinsi Jambi. Daun capo dan daun sembung rambat diambil sebanyak 2 kg, kemudian akan dicuci dengan air mengalir hingga bersih, setelah itu daun capo dikeringkan ditempat yang tidak terkena sinar matahari langsung. Sampel yang sudah kering dihaluskan menggunakan blender hingga menjadi serbuk 
(Polakitan et al., 2017).

\subsubsection{Ekstraksi Simplisia}

Proses ekstraksi masing masing daun capo dan daun sembung rambat dilakukan perendaman dengan etanol $70 \%$ hingga permukaan serbuk terendam, dilakukan pada suhu ruangan dan dijauhkan dari cahaya matahari langsung. Pada saat maserasi tersebut dilakukan pengadukan menggunakan batang pengaduk. Lalu hasil maserasi disaring menggunakan kertas saring sehingga nanti akan didapatkan filtrat. Maserasi dilakukan hingga warna pelarut menjadi jernih, dan semua filtrat yang dihasilkan akan dicampurkan, kemudian dipekatkan menggunakan rotary evaporator pada suhu $50^{\circ} \mathrm{C}$ sampai akhirnya didapatkan hasil ekstrak kental (Polakitan et al., 2017). Hasil rendemen masingmasing ekstrak daun capo dan sembung rambat dapat dihitung dengan rumus berikut :

$\%$ rendamen $=\frac{\text { Bobot ekatrak yang diperoleh (Gram) }}{\text { bohot ampal aimplisia (gram) }} \times 100 \%$

2.2.4. Uji Sitotoksik Ekstrak Capo, Ekstrak Sembung Rambat, dan Kombinasi Ekstrak Capo dan Sembung Rambat

a. Persiapan Larva Udang (Artemia salina Leach)

Soliter atau wadah pembiakan larva untuk penetasan larva udang yang telah berisi air laut $(\mathrm{pH} 7,5-8,5)$, ditaburkan telur larva udang sebanyak 1 gram. Soliter/wadah pembiakan larva tersebut disimpan di bawah lampu dengan sisi terbuka menghadap lampu dan diberi oksigen melalui aerator. Aerator mengalirkan udara yang berisi oksigen ke dalam media penetasan telur larva udang yakni air laut. Setelah 48 jam telur akan menetas dan siap dipakai untuk pengujian, kemudian dipindahkan ke wadah lain sebagai tempat untuk memudahkan pengambilan larva yang sudah menetas pada saat dilakukan pengujian. Larva udang yang akan diuji diambil sebanyak 10 larva udang dengan cara dipipet (Noviardi et al., 2019). 
b. Uji Sitotoksik

Ekstrak kental etanol $70 \%$ daun capo dan daun sembung rambat ditimbang sebanyak $50 \mathrm{mg}$ dalam $100 \mathrm{~mL}$ lalu dibuat larutan uji dengan konsentrasi 500 ppm sebagai larutan induk, ekstrak kental daun capo dan daun sembung rambat dengan perbandingan ekstrak capo dan sembung rambat 1:1 lalu dibuat dengan konsentrasi 60 ppm, 50 ppm, 40 ppm, 30 ppm, 20 ppm dalam $10 \mathrm{ml}$ air laut dengan cara pengenceran. Untuk kontrol air laut. Jumlah hewan uji larva udang 10 ekor setiap pengujian dilakukan 3 kali pengulangan. (Widyastuti et al., 2019).

\section{HASIL DAN PEMBAHASAN}

\subsection{Hasil ekstraksi}

Data rendemen simplisia dan ekstrak kental dari daun capo dan sembung rambat dapat dilihat pada Tabel 1 dan Tabel 2

Tabel 1. Hasil rendemen ekstrak capo

\begin{tabular}{llcc}
\hline Proses & Bahan & Berat $(\mathrm{g})$ & Rendemen $(\%)$ \\
\hline Sortasi Basah & Daun Segar & 2000 & - \\
Pengeringan & Simplisia & 500 & 25 \\
Ekstraksi & Ekstrak Kental & 7,8 & 1,5 \\
\hline
\end{tabular}

Tabel 2. Hasil rendemen ekstrak sembung rambat

\begin{tabular}{llrc}
\hline Proses & Bahan & Berat $(\mathrm{g})$ & Rendemen $(\%)$ \\
\hline Sortasi Basah & Daun Segar & 20.000 & - \\
Pengeringan & Simplisia & 4.400 & 22 \\
Ekstrasi & Ekstrak Kental & 399 & 9 \\
\hline
\end{tabular}

\subsection{Pengujian Fitokimia Capo, Sembung Rambat, Kombinasi}

Hasil dari pengujian fitokimia dapat diketahui metabolit sekunder yang terdapat pada ekstrak daun capo, sembung rambat, kombinasi capo dan sembung rambat yang 
dapat dilihat pada Tabel 3 .

Tabel 3. Hasil Pengujian Skrining Fitokimia Ekstrak Capo, Sembung Rambat, Kombinasi Capo dan Sembung Rambat

\begin{tabular}{lccc}
\hline $\begin{array}{l}\text { Golongan } \\
\text { Senyawa }\end{array}$ & $\begin{array}{c}\text { Ekstrak } \\
\text { Capo }\end{array}$ & $\begin{array}{c}\text { Ekstrak } \\
\text { Sembung } \\
\text { Rambat }\end{array}$ & $\begin{array}{c}\text { Ekstrak } \\
\text { Kombinasi }\end{array}$ \\
\hline Alkaloid & - & - & - \\
- (Mayer) & - & + & + \\
- (Wagner) & + & + & + \\
- (Dragendrof) & + & + & + \\
Flavonoid & - & - & - \\
Tanin & + & - & - \\
Saponin & + & + & + \\
Fenolik & + & + & + \\
Steroid dan & + & + & + \\
Terpenoid & + & + & + \\
Kuinon & + & & + \\
\hline
\end{tabular}

Keterangan :(+) : Mengandung Senyawa

(-) : Tidak Mengandung Senyawa

\subsection{Hasil uji sitotoksik}

Hasil uji sitotoksik terhadap ekstrak sembung rambat, ekstrak capo, maupun ekstrak kombinasi dapat dilihat pada Tabel. 4. 
Tabel 4. Hasil Uji Aktivitas Sitotoksik Tumbuhan Capo, Sembung Rambat, Kombinasi Capo dan Sembung Rambat

\begin{tabular}{|c|c|c|c|c|c|c|c|c|c|c|c|}
\hline \multirow[t]{2}{*}{ Sampel } & \multirow[t]{2}{*}{$\begin{array}{l}\text { Konsentrasi } \\
(\mathrm{ppm})\end{array}$} & \multirow{2}{*}{$\begin{array}{l}\text { Log Konsentrasi } \\
\text { (X) }\end{array}$} & \multicolumn{3}{|c|}{$\begin{array}{c}\text { Pengulangan } \\
\text { Kematian Larva }\end{array}$} & \multirow[t]{2}{*}{$\begin{array}{l}\text { Rata- } \\
\text { Rata }\end{array}$} & \multirow[t]{2}{*}{ SD } & \multirow[t]{2}{*}{$\begin{array}{l}\% \\
\text { kematian }\end{array}$} & \multirow[t]{2}{*}{$\begin{array}{l}\text { Probit } \\
\text { (Y) }\end{array}$} & \multirow{2}{*}{$\begin{array}{l}\text { Persamaan Regresi } \\
\qquad(\mathrm{Y}=\mathrm{ax}+\mathrm{b})\end{array}$} & \multirow[t]{2}{*}{$\begin{array}{l}\mathrm{LC}_{50} \\
(\mathrm{ppm})\end{array}$} \\
\hline & & & 1 & 2 & 3 & & & & & & \\
\hline \multirow[t]{5}{*}{ Daun Capo } & 60 & 1,78 & 8 & 8 & 8 & 8,0 & 0,00 & $80 \%$ & 5,84 & \multirow{5}{*}{$\begin{array}{l}y=4,2486 x- \\
1,8928\end{array}$} & \multirow{5}{*}{41,68} \\
\hline & 50 & 1,70 & 6 & 5 & 7 & 6,0 & 1,00 & $60 \%$ & 5,25 & & \\
\hline & 40 & 1,60 & 4 & 3 & 5 & 4,0 & 1,00 & $40 \%$ & 4,76 & & \\
\hline & 30 & 1,48 & 3 & 2 & 3 & 2,6 & 0,58 & $26 \%$ & 4,36 & & \\
\hline & 20 & 1,30 & 1 & 1 & 1 & 1,0 & 0,00 & $10 \%$ & 3,72 & & \\
\hline Sembung & 60 & 1,78 & 9 & 9 & 10 & 9,3 & 0,47 & $93 \%$ & 6,48 & \multirow{5}{*}{$y=3,451 x-0,013$} & \multirow{5}{*}{28,18} \\
\hline \multirow[t]{4}{*}{ Rambat } & 50 & 1,70 & 8 & 7 & 7 & 7,3 & 0,47 & $73 \%$ & 5,61 & & \\
\hline & 40 & 1,60 & 7 & 6 & 6 & 6,3 & 0,47 & $63 \%$ & 5,33 & & \\
\hline & 30 & 1,48 & 5 & 5 & 5 & 5,0 & 0,00 & $50 \%$ & 5,00 & & \\
\hline & 20 & 1,30 & 3 & 4 & 4 & 3,6 & 0,47 & $36 \%$ & 4,64 & & \\
\hline \multirow{5}{*}{$\begin{array}{l}\text { Kombinasi } \\
\text { Capo dan } \\
\text { Sembung } \\
\text { Rambat }\end{array}$} & 60 & 1,78 & 10 & 10 & 9 & 9,6 & 0,58 & $96 \%$ & 6,75 & \multirow{5}{*}{$\begin{array}{l}y=2,8844 x \\
+1,6238\end{array}$} & \multirow{5}{*}{14,79} \\
\hline & 50 & 1,70 & 10 & 9 & 9 & 9,3 & 0,58 & $93 \%$ & 6,48 & & \\
\hline & 40 & 1,60 & 9 & 8 & 10 & 9,0 & 1,00 & $90 \%$ & 6,28 & & \\
\hline & 30 & 1,48 & 8 & 8 & 9 & 8,3 & 0,58 & $83 \%$ & 5,95 & & \\
\hline & 20 & 1,30 & 7 & 6 & 6 & 6,3 & 0,58 & $63 \%$ & 5,33 & & \\
\hline $\begin{array}{l}\text { Kontrol } \\
\text { (air laut) }\end{array}$ & 0 & 0,00 & 0 & 0 & 0 & 0,0 & 0,00 & $0 \%$ & 0,00 & - & \\
\hline
\end{tabular}


Ekstraksi sampel dilakukan dengan menggunakan metode maserasi. Pemilihan pelarut dalam proses ekstraksi dapat mempengaruhi hasil rendemen, semakin tinggi polaritas pelarut maka semakin banyak pula hasil rendemen yang didapat (Ratu et al, 2018).

Pengujian skrining fitokimia terhadap ekstrak capo dan sembung rambat yang dilakukan oleh peneliti sebelumnya yaitu Maslahat dkk dan Perawati dkk memiliki kandungan metabolit sekunder flavonoid, alkaloid, tanin, terpenoid dan saponin. Sedangkan pada pengujian ekstrak yang dilakukan oleh peneliti terhadap capo, sembung rambat maupun kombinasi capo dan sembung rambat didapatkan hasil bahwa ekstrak memiliki kandungan metabolit sekunder alkaloid dengan 3 reaksi yaitu mayer, dragendorf dan wagner, flavonoid, saponin, steroid, terpenoid, fenolik dan kuinon. Pada peneliti-peneliti sebelumnya diketahui bahwa reaksi wagner terdeteksi pada sembung rambat dibandingkan dengan capo, begitu juga dengan metabolit sekunder saponin terdeteksi pada capo dibandingkan dengan sembung rambat (Maslahat, dkk, 2018) (Perawati, dkk, 2018).

Pengujian dilakukan dengan metode BSLT menggunakan larva udang Artemia salina Leach. Dalam pengujian ini digunakan larva berumur 48 jam karena larva sudah mempunyai mulut dan saluran pencernaan serta cadangan makanannya sudah mulai habis sehingga larva mulai mencari makanan dan lebih sensitif(Fadli et al, 2019).

Pengujian sitotoksik dengan metode BSLT menghasilkan nilai LC $_{50}$ pada sembung rambat dengan nilai $\mathrm{LC}_{50} 28,18$ ppm dengan kategori sangat toksik, dan untuk ekstrak capo sebesar 41,68 ppm dengan kategori kuat. Pada ekstrak kombinasi capo dan sembung rambat didapatkan nilai $\mathrm{LC}_{50}$ sebesar 14,79 ppm dengan kategori sangat toksik. Berdasarkan hasil yang didapat ekstrak kombinasi capo dan sembung rambat memberikan efek sitotoksik lebih baik daripada ekstrak tunggal. Hal ini dikarenakan ekstrak daun capo dan sembung rambat memiliki efek yang sinergis terhadap kematian larva udang Artemia salina Leach. Efek sinergis obat merupakan 
efek dua obat atau senyawa yang memiliki efek terapi yang sama sehingga saling menguatkan efek terapi baik dengan mekanisme aksi yang sama maupun berbeda. Tingginya aktivitas sitotoksik sembung rambat dibandingkan capo diduga karena adanya kandungan senyawa alkaloid sembung rambat lebih dominan dibandingkan dengan capo. Dimana alkaloid dapat menyebabkan gangguan sistem pencernaan pada larva Artemia salina Leach (Sufiana, dkk, 2019).

Pada penelitian sebelumnya yang dilakukan oleh Tianandari dkk yaitu melakukan pengujian pada ekstrak etanol buah ketumbar yang mana diperoleh hasil bahwa persentase kematian larva Arthemia salina Leach tertinggi pada konsentrasi 500 ppm dan terendah pada konsentrasi 12,5 ppm. Persentase kematian semakin meningkat dengan peningkatan konsentrasi larutan uji. Hal tersebut menunjukkan bahwa setiap konsentrasi memiliki pengaruh yang berbeda pada angka kematian larva Artemia salina Leach, semakin tinggi konsentrasi ekstrak maka semakin tinggi pula jumlah kematian larva. Dari hasil probit yang peneliti dapat terlihat bahwa ekstrak kombinasi lebih toksik dari pada ekstrak tunggal. Ekstrak dikatakan aktif bila dapat menyebabkan kematian 50\% hewan uji pada konsentrasi $<1000$ ppm, oleh karena itu dapat disimpulkan bahwa ekstrak capo, sembung rambat, kombinasi capo dan sembung rambat mempunyai potensi sebagai sitotoksik ( Tianandari, dkk, 2019).

Tanaman capo memiliki kandungan terpenoid, flavonoid, fenolik dan beberapa golongan alkaloid yang telah diketahui aktif dalam pengujian aktivitas sitotoksik, dimana hasil penelitian sebelumnya yang dilakukan oleh Fadli mengatakan bahwa ekstrak kulit batang tumbuhan kangkang katup (Bauhunia semibifida Roxb) memiliki kandungan terpenoid, flavonoid, fenolik dan beberapa golongan alkaloid. (Fadhli, et al, 2019). Pada uji skrining fitokimia ditemukan bahwa ekstrak sembung rambat mempunyai metabolit sekunder seperti flavonoid, fenolik, steroid, terpenoid, kuinon, saponin dan turunan alkaloid dragendorf merupakan zat aktif yang asing bagi artemia. Pada penelitian sebelumnya terkait pengujian ekstrak kulit jengkol (Pithecellobium jiringa), senyawa bioaktif yang terkandung di dalam ekstrak kulit 
jengkol antara lain terpenoid, alkaloid, flavonoid, saponin, dan tanin dimana senyawa terpenoid memegang peranan sebagai anti feedant (menghambat dalam proses makan larva).

Flavonoid memiliki aktivitas sebagai sitotoksik, sedangkan kandungan senyawa lainnya seperti senyawa alkaloid dapat menyebabkan gangguan sistem pencernaan. Selain itu ia menghambat reseptor perasa pada daerah mulut hal ini yang menyebabkan larva gagal mendapatkan stimulus rasa sehingga tidak mengenali makanannya karena alkaloid bertindak sebagai racun senyawa-senyawa tersebut bertindak sebagai racun perut (Sinaga, et al, 2018).

\section{KESIMPULAN DAN SARAN}

\subsection{Kesimpulan}

Berdasarkan pada hasil penelitian yang dilakukan dapat disimpulkan bahwa ekstrak kombinasi dan ekstrak sembung rambat memiliki nilai sitotoksik yang lebih tinggi dibandingkan ekstrak capo.

\subsection{Saran}

Perlunya penelitian lanjutan untuk mengisolasi metabolit sekunder yang berpotensi sitotoksik pada daun sembung rambat dan daun capo.

\section{REFERENSI}

Afifah Bambang, S(2019) 'Efek antihipertensi ekstrak etanol daun sembung (blumea balsamifera) pada model hewan uji induksi epinefrin'. Cimahi, Indonesia: Jurnal Farmasi Indonesia, 11(1) pp. 466-472,

Alfiah, R. R., Khotimah, S. and Turnip, M. (2015) 'Efektivitas Ekstrak Metanol Daun Sembung Rambat ( Mikania micrantha Kunth ) Terhadap Pertumbuhan Jamur candida albicans', Jurnal Protobiont, 4(1), pp. 52-57.

Apriandi, R., Lukmayani, Y. and Abdul Kodir, R. (2016) 'Penetapan kadar flavonoid total dan aktivitas antioksidan dari ekstrak dan fraksi daun Sembung rambat (Mikania micrantha Kunth)', Prosiding Farmasi, 2(2), pp. 592-597.

Aried Eriadi, Ifora, S. A. (2019) 'Uji Sitotoksitas Sub Akut Ekstrak Etanol Daun Sembung ( Blumea balsamifera L . DC ) Terhadap Fungsi Hati Dan Ginjal', Jurnal Farmasi Higea, 11(1), pp. 23-31. 
Damayanti, K., Nugroho, A. E. and Nurrohmad, A. (2019) 'Aktivitas Antiasma Rebusan Kombinasi Daun Sembung (Blumea balsamifera L. DC.), Herba Patikan Kebo (Euphorbia hirta L.), Biji Kemukus (Piper cubeba L.) Dan Rimpang Teki (Cyperus rotundus Linn.) Pada Marmut Jantan Secara In Vitro Dan In Vivo', Jurnal Farmasi Indonesia, 14(2), pp. 133-141.

Dou, X. et al. (2014) 'The anti-tumor activity of Mikania micrantha aqueous extract in vitro and in vivo', Cytotechnology, 66(1), pp. 107-117.

Fadhli, H dan Hasanah, S. (2019) 'Uji Sitotoksik Ekstrak Kulit Batang Tumbuhan Kangkang Katup (Bauhinia semibifida Roxb) dengan Metode Brine Shrimp Lethality Test (BSLT)', SCIENTIA Jurnal Farmasi dan Kesehatan, 9(2), pp. 141-145.

Iga. Wita Kusumawati, I. B. A. Y. (2016) 'Antioxidant and antibacterial capacity of loloh sembung (Blumea balsamifera) based on Extraction method', Majalah Obat Tradisional, 21(3), pp. 143-148.

Kemenkes RI (2019) 'Artikel Hari Kanker Sedunia 2019', 31 Januari, 1(1), pp. 1-2.

Lesmana, H. et al. (2018) 'Pengobatan tradisional pada masyarakat tidung kota Tarakan: study kualitatif kearifan lokal bidang kesehatan', Medisains, 16(1), pp. 31-41.

Lestari, D., Kartika, R. and Marliana, E. (2019) 'Uji Brine Shrimp Lethality Test (BSLT) Umbi Bawang Tiwai (Eleutherine bulbosa (Mill.) Urb) Dan Uji Toksisitas Akut Fraksi Aktif', Jurnal Riset Kefarmasian Indonesia, 1(1), pp. 1-10.

Maslahat, M. and Yuliani, N. (2018) 'Kandungan Fitokimia, Klorofil dan Biomassa Daun Sembung Leaves ( Blumea balsamifera )', Jurnal Sains Natural Universitas Nusa Bangsa, 4(1), pp. 11-25.

Mayang Tari, Lidia, N. L. (2016) 'Uji aktivitas antibakteri terhadap beberapa fraksi daun sembung rambat (Mikania micrantha Kunth.) terhadap bakteri penyebab penyakit kulit', Jurnal Ilmiah Bakti Farmasi, 1(2), pp. 49-54.

Mutiah, R., Listyana, A., Suryadinata, A.(2017) 'Aktivitas Antikanker Kombinasi Ekstrak Benalu Belimbing (Macrosolen cochinensis) dan Bawang Sabrang (Eleutherine palmifolia (L) Merr.) pada Sel Kanker Serviks (SEL HeLa)', Traditional Medicine Journal, 22(223), pp. 146-152.

Noviardi, H. et al. (2019) 'Sitotoksitas kombinasi ekstrak etanol 70\% daun petai cina (Leucaena leucocephala (Lam.) de Wit) dan kulit jengkol (Archidendron jiringa (Jack) I.C.Nielsen) dengan metode Brine Shrimp Lethality Test', Riset Informasi Kesehatan, $8(1)$, pp. $9-15$.

Firmansyah, Nursamu (2017) 'Pemanfaatan Daun Sembung ( Blumea balsamifera ) Sebagai Obat Tradisional di Kampung Jawa Kecamatan Kejuruan Muda Kabupaten Aaceh Tamiang Tahun 2015', Jurnal Jeumpa, 4(2), pp. 8-13.

Perawati, S. et al. (2019) 'Aktivitas Koagulan Ekstrak dan Fraksi Daun Sembung Rambat (Mikania micrantha Kunth.)', Chempublish Journal, 4(1), pp. 30-37.

Perawati, S., Andriani, L. and Pratiwi, P. (2018) 'Aktivitas Antibakteri Ekstrak Etanol Daun Sembung Rambat (Mikania micrantha Kunth)', Chempublish Journal, 3(2), pp. 40-45.

Raka, S. C. et al. (2019) 'Assessment of phytochemical, cytotoxic, anthelmintic and thrombolytic activity of mikania micrantha leaves: a new addition in phytomedicine', Pharmacologyonline, 1(1), pp. 246-255.

Ratu, A. P. and Wirasti, W. (2018) 'Uji Sitotoksik daun kemangi (Ocimum Basilicum L.) dengan metode brine shrimp lethality test(BSLT)', Jurnal Farmasi Sains dan Praktis, 
4(2), pp. 15-19.

Semiawan, F., Ahmad, I. and Masruhim, M. A. (2015) 'Aktivitas Antiinflamasi Ekstrak Daun Kerehau (Callicarpa longifolia L.)', Jurnal Sains dan Kesehatan, 1(1), pp. 1-4.

Sinaga, I., Rosliana, R. and Riyanto, R. (2018) 'Uji Sitotoksik (LC50 - 24 Jam) Ekstrak Kulit Jengkol Pithecellobium jiringa) Terhadap Larva UdangArtemia salina Leach', Jurnal Biosains, 4(2), pp. 96-101.

Sufiana, Harlina, (2019) 'uji aktivitas antioksidan dan sitotoksisitas campuran ekstrak metanol kayu sepang (caesalpinia sappan 1.) dan kulit kayu manis (cinnamomum burmannii b.)'JKK,3(2), pp. 50-55.

Widyastuti, S. et al. (2019) 'Uji Toksisitas Akut Ekstrak Daun Suruhan (Peperomia Pellucida (L.) Kunth) Terhadap Larva Udang (Artemia Salina Leach)', Jurnal Herbal Indonesia, 1(1), pp. 10-17. 